\title{
A review of the amino acid metabolism in placental function response to fetal loss and low birth weight in pigs
}

\author{
Chengquan Tan ${ }^{1 \dagger}$, Zihao Huang ${ }^{1 \dagger}$, Wenyu Xiong ${ }^{1}$, Hongxuan Ye ${ }^{1}$, Jinping Deng ${ }^{1^{*}}$ (D) and Yulong Yin ${ }^{*^{*}}$
}

\begin{abstract}
The fertility of sows mainly depends on the embryo losses during gestation and the survival rate of the postfarrowing piglets. The selection of highly-prolific sows has been mainly focused on the selection of genotypes with high ovulatory quota. However, in the early- and post-implantation stages, the rate of embryo losses was increased with the increase of zygotes. Among the various factors, placental growth and development is the vital determinant for fetal survival, growth, and development. Despite the potential survival of fetuses with deficient placental development, their life-conditions and growth can be damaged by a process termed intrauterine growth retardation (IUGR). The newborn piglets affected by IUGR are prone to increased morbidity and mortality rates; meanwhile, the growth, health and welfare of the surviving piglets will remain hampered by these conditions, with a tendency to exacerbate with age. Functional amino acids such as glycine, proline, and arginine continue to increase with the development of placenta, which are not only essential to placental growth (including vascular growth) and development, but can also be used as substrates for the production of glutathione, polyamines and nitric oxide to benefit placental function in many ways. However, the exact regulation mechanism of these amino acids in placental function has not yet been clarified. In this review, we provide evidence from literature and our own work for the role and mechanism of dietary functional amino acids during pregnancy in regulating the placental functional response to fetal loss and birth weight of piglets. This review will provide novel insights into the response of nutritionally nonessential amino acids (glycine and proline) to placental development as well as feasible strategies to enhance the fertility of sows.
\end{abstract}

Keywords: Amino acids, Birth weight, Fetal loss, Pigs, Placenta

\section{Introduction}

During the last two decades, the number of total born piglets per litter has been increased through genetic selection. Meanwhile, with the increase of litter size, the

\footnotetext{
* Correspondence: dengjinping@scau.edu.cn; yinyulong@isa.ac.cn

${ }^{\dagger}$ Chengquan Tan and Zihao Huang contributed equally to this work.

'Guangdong Provincial Key Laboratory of Animal Nutrition Control, National Engineering Research Center for Breeding Swine Industry, Institute of Subtropical Animal Nutrition and Feed, College of Animal Science, South China Agricultural University, Guangzhou 510642, Guangdong, China ${ }^{2}$ National Engineering Laboratory for Pollution Control and Waste Utilization in Livestock and Poultry Production, Institute of Subtropical Agriculture, Chinese Academy of Sciences, Changsha 410125, Hunan, China
}

incidence of stillbirth increased and individual pig birth weight decreased, thus reducing the reproductive efficiency of sows $[1,2]$. The largest contributor to a higher level of production is the number of live-born piglets of gilts or sows, which is directly affected by ovulation rate, fertilization rate, and conceptus survival to term. Sow is characterized with multi-ovulatory ovaries, ovulating approximately $20-30$ follicles [3]. With a fertilization rate close to $90 \%$ [4], the number of early embryos can potentially reach $18-27$. However, at farrowing, litter size is reduced to 9-13 piglets per sow due to the influence of many factors $[5,6]$. One factor we must emphasize is

(c) The Author(s). 2022 Open Access This article is licensed under a Creative Commons Attribution 4.0 International License, which permits use, sharing, adaptation, distribution and reproduction in any medium or format, as long as you give appropriate credit to the original author(s) and the source, provide a link to the Creative Commons licence, and indicate if changes were made. The images or other third party material in this article are included in the article's Creative Commons licence, unless indicated otherwise in a credit line to the material. If material is not included in the article's Creative Commons licence and your intended use is not permitted by statutory regulation or exceeds the permitted use, you will need to obtain permission directly from the copyright holder. To view a copy of this licence, visit http://creativecommons.org/licenses/by/4.0/ The Creative Commons Public Domain Dedication waiver (http://creativecommons.org/publicdomain/zero/1.0/) applies to the data made available in this article, unless otherwise stated in a credit line to the data. 
the spontaneous conceptus loss. Two major waves of spontaneous embryonic or fetal loss have been documented in pigs: the first one occurs during the periattachment period (accounting for approximately 30\% of total conceptus loss) and the second during midgestation (accounting for an additional 10-15\% of conceptus loss) [7]. During the peri-attachment period (day 12-30 of pregnancy) for the attachment of conceptuses to the receptive endometrium $[8,9]$, variations in embryonic growth and elongation rates may alter the uterine environment, leading to lower survivability of lessdeveloped conceptuses. During the mid-gestation period (day 50-70 of pregnancy), increased fetal growth may cause some conceptus attachment sites to exceed their uterine space, leading to conceptus arrest of adjacent littermates $[8,9]$.

Pigs exhibit the most severe (up to $25 \%$ ) naturally occurring intrauterine growth retardation (IUGR) among livestock species $[10,11]$. At present, IUGR piglets are culled on farms, and there is no nutritional support to increase their growth or survival during the suckling and postweaning periods. Moreover, large intra-litter variation in conceptus development is another major problem facing the global swine industry [12]. Birth weights of piglets can differ by up to three-fold in the same litter because the size, length and surface area of porcine placentae vary markedly among the conceptuses within the same uterus [13]. Heterogeneity in piglet weights among and within litters on the same farm increases the cost and challenge of managing a modern swine production system [14].

Studies over past few years have attempted to clearly delineate the causality related to spontaneous fetal loss and low weight of live-born piglets [4, 7, 15-17], which is attributed to uterine capacity [18], genetics [19], environment [20], immune mechanisms [21], and placental development [10, 22, 23]. However, the vital causes for porcine spontaneous conceptus loss and fetal growth retardation are still not well understood. The important contributors appear to be the placental development and function (deficits in vasculature) in early gestation and inadequate uterine capacity at all periods of gestation $[10,24,25]$ rather than simply the number of ovulations or embryos [26].

\section{Early embryonic development and placentation in pigs}

For the survival of conceptuses to term, we must coordinate the development of placentae and the specific adaptation of pregnancy to growth and development. For conceptus attachment and establishment or placental development, a series of events must proceed to ensure the uterine receptivity of the developing conceptuses, which include blastocyst hatching, hormone secretion, elongation into a filamentous conceptus and implantation and attachment $[7,15]$.

After fertilization, the zygote undergoes timedependent mitotic divisions, resulting in embryos at different cleavage stages. A pig embryo enters the uterus between the four- to eight-cell stage and develops into a blastocyst shortly thereafter (around day 5). Between day 11-12 of pregnancy, the blastocyst secrets estrogen, changing the endometrial secretion of prostaglandin F2 alpha, allowing it to directly enter the uterine capillaries and release into the uterine lumen, eventually preventing the luteolysis of the corpus luteum and maintaining the progesterone secretion essential for a successful pregnancy $[27,28]$. Between day 6 and 7 of pregnancy, the pig conceptus passes into the uterus as a spherical 100 $\mathrm{mm}$ blastocyst within a zona pellucida. At this stage, the development of pig embryos diverges dramatically from rodents or primates, and the presumptive placental membranes (trophectoderm and endoderm) elongate rapidly to a filamentous form by day 16 [15]. Placentation in the pig relies on conceptus elongation to increase the available surface area for gas and nutrient exchange [15].

Implantation is the process for the attachment of the blastocyst to the uterus for the juxtaposition of embryonic and maternal circulation, leading to the establishment of a functional placenta and successful pregnancy, with the initial attachment process starting around day 12 during gestation [29]. Peri-implantation conceptus elongation and implantation in pigs is modulated by the secretion of the endometrium in response to factors from the ovary (progesterone), the conceptus (estrogen, interleukin-1beta, interferons delta and gamma, and transforming growth factor beta) and endometrium (transforming growth factor beta and fibroblast growth factor 7) [15]. These complex events are orchestrated through, among others, four important cell signaling pathways for endocrine, paracrine, autocrine, and juxtracrine communication between conceptus and uterus, and deficiencies of these events are reflected by a high rate of conceptus mortality during the peri-implantation period of pregnancy [30]. Particularly, further production of oestrogen by the blastocyst within day 15-30 of pregnancy stimulates the secretion from the uterine epithelium and glands [27], leading to the production of specific proteins which are thought to be involved in the growth of the conceptus and the subsequent immunological readjustment necessary for successful implantation [31]. Collectively, communication and crosstalk between the peri-attachment conceptus and the endometrium are important for survival and placentation.

Between day 15 and 20 of pregnancy, trophoblastic and uterine membranes come close together, enabling the interdigitating microvilli to develop between the 
apical domes of the uterine epithelium and the trophoblast to cover the entire placenta except for the openings of uterine glands, leading to the transition from primarily histotrophic to hemotrophic nutrition [32]. Along the uterine gland openings, simple structures called areola [33] begin to form at day 25-30 of pregnancy while dome-shaped structures over the openings of uterine glands and the numbers are maximized by day 70 of gestation [34].

Placentae develop earlier than fetuses in gilts. Between day 20 and 60 of pregnancy, the porcine placenta begins to grow rapidly, with a significant increase in weight, size and surface area, followed by near-maximum development and vascularization at day 70 of pregnancy $[7,35]$. During the development of placenta, the demand for amino acids increases gradually, and the placental total mass of amino acids increases linearly as gestation progresses [10, 36]. Glycine, proline, arginine, and alanine, rather than other amino acids, contribute to the increase of total amino acids with the progression of pregnancy, especially glycine and proline $[10,36]$. The concentrations of proline in porcine placenta increase between day 20 and 40 of pregnancy, remain high until day 60 of gestation, and decline thereafter, which is consistent with the rapid growth of placenta in the first trimester of pregnancy [37]. These results suggest that the maturation and development of placenta may require more such amino acids to continue the synthesis of connective tissues and collagen, as well as support cell steady proliferation and angiogenesis. Moreover, in contrast to the placenta whose weight tends to stabilize, the growth rate of fetuses is very high after day 60 of gestation [38], indicating that the increased placental weight might promote fetal growth. Placental vascularization and angiogenesis are necessary for the marked increase of the utero-placental blood flow during this period to supply nutrients from mother to fetus for optimal growth $[22,39]$.

\section{Morphology and structure of the porcine placenta}

The swine placenta is a typical diffuse epitheliochorial organ without invasion [40], i.e., with neither invasion of fetal tissue into the maternal endometrium nor the occurrence of endometrial decidualization. Almost the entire surface of the allantochorion (embryonic membrane consisting of a fused allantois and chorion) is involved in the formation of placenta. Porcine fetuses have individual fetal membranes, and on day 39-55 of gestation, large placental zones of the individual conceptuses are terminated by the two extremities of the fetal sacs that include para-placental and ischemic zones (necrotic tips) [41]. Maternal and fetal microvilli appose and interdigitate, with a clear distinction between maternal and fetal tissues (semi-placenta). Meanwhile, maternal and fetal blood is separated by six tissue layers (Fig. 1) to form a firm barrier, which can even prevent maternal antibodies from passing through fetuses during gestation [42]. Since no invasion occurs, much of the placenta/embryonic development depends on the uterine milk or embryotroph (areolae). Interestingly, although the ungulate placenta is epitheliochorial, the placental barrier in certain regions is thinner than that found in carnivores with the endotheliachorial placenta (in this type of placenta, the endometrial epithelium under the placenta does not survive implantation, and fetal chorionic epithelial cells come in contact with maternal endothelial cells) [43]. Moreover, although epitheliochorial placentae are multilayered, the distance between fetal and maternal blood is minimized by the indentation of maternal capillaries into the uterine epithelium and fetal capillaries into the trophoblast [31, 33]. Another important advantage of epitheliochorial placentation is the detachment of the placenta at parturition with minimal damage to the uterus, which may accelerate the recovery of postpartum receptivity of the uterus as seen in pigs and horses [33].

\section{Role of amino acids in regulating placental function in sows}

Among the nutrients required by pregnant sows, amino acids play the most important role in placental growth due to their involvement in the synthesis of sufficient proteins to support the proliferation of trophectoderm and endothelial cells [10]. Amino acids are not only the building blocks of proteins in cells, but also precursors for synthesis of nitrogenous substances (e.g., nitric oxide (NO), polyamines, and glutathione) essential for placental growth and angiogenesis, conceptus development or scavenging free radicals to prevent placental oxidative damage $[10,44,45]$. As mentioned earlier, the placental demand of amino acids varies markedly with the extension of gestation, so the supply of amino acids to the placenta must be controlled to ensure an adequate supply of each amino acid. Among all the amino acids measured in the placenta, glycine is the highest in content, followed by glutamate, proline, and arginine on day 60 of gestation [10]. Alanine, aspartate, asparagine, glutamate, and glutamine are synthesized from branched-chain amino acids and glucose in the porcine placenta [46]. As little is known about the de novo synthesis of glycine and proline in the placenta currently, this review mainly focuses on the roles of glycine, proline, and arginine in the regulation of placental function.

\section{Glycine}

Glycine, the most abundant amino acid in oviductal, uterine and follicular fluids, plays a vital role during oocyte maturation, fertilization, and early embryonic development in pigs [47]. The catabolism of glycine provides 


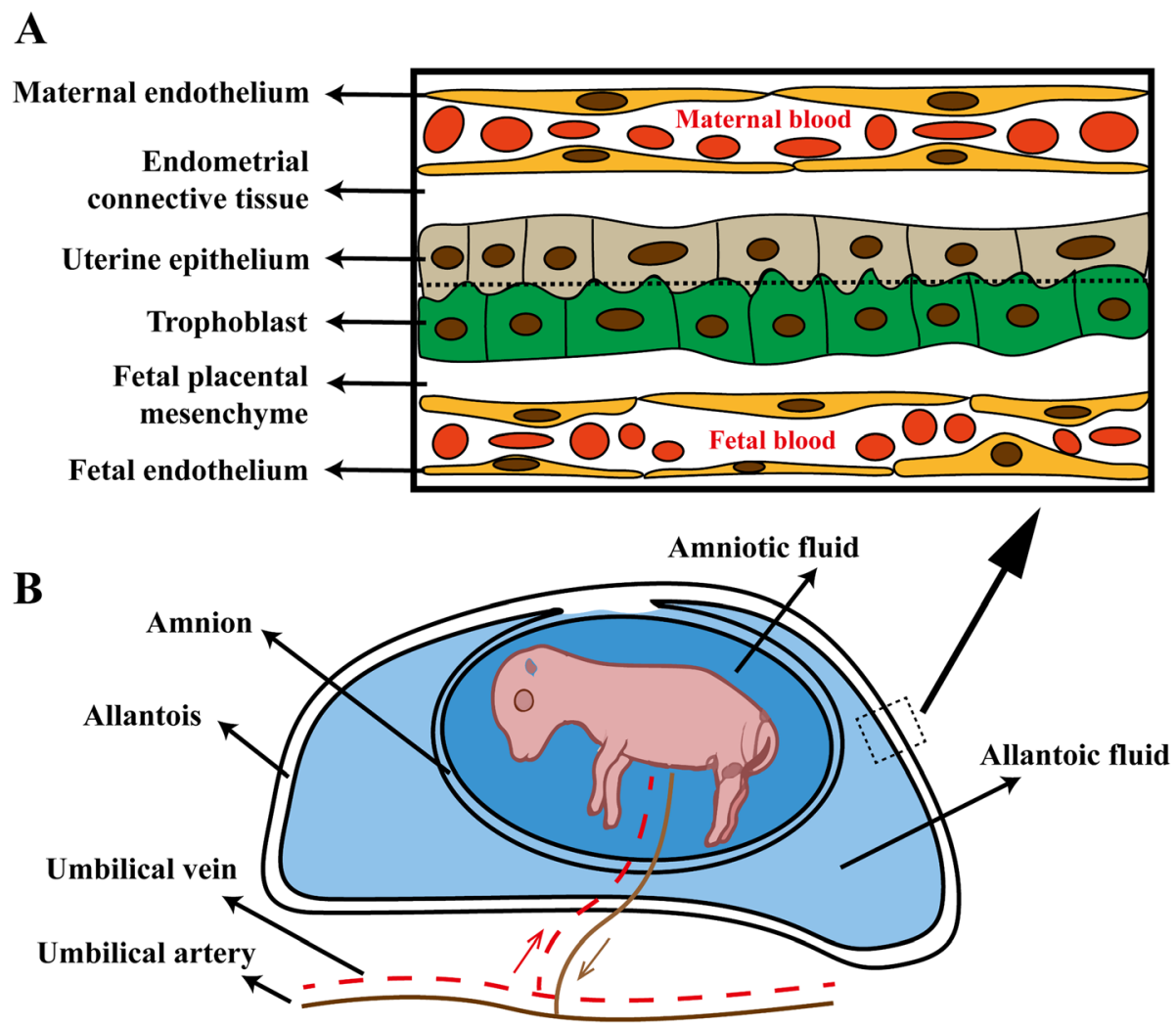

Fig. 1 Porcine placental barrier and conceptus. Representations of the placental barrier in swine (A) and conceptus within the uterine horn (B). Note that the allantois also supports the vascular elements of the epitheliochorial placenta of the pig. The amnion is filled with amniotic fluid that facilitates the embryo/fetus to allow it to develop symmetrically and not adhere to other tissues

a methyl group to folic acid for DNA synthesis and methylation of homocysteine [48]. In this pathway, the glycine cleavage system is catalyzed by a complex of four proteins, and among them, T-protein requires tetrahydrofolate as a cofactor and induces the formation of ammonia and 5,10-methylene-tetrahydrofolate [49]. In sows, glycine is the most abundant amino acid in the oviduct and uterine fluids during diestrus [50] and in the allantoic fluid on day 30 of gestation [51]. Therefore, the metabolic provision of glycine to uterus should be adequate for an optimal folate response. Indeed, dietary supplementation of folic acid + glycine is shown to optimize embryo development in multiparous Yorkshire-Landrace sows [52]. Furthermore, glycine supplementation rather than urea or alanine supplementation is found to play an important role in maternal Samino acid metabolism in pregnancy and fetal cardiovascular development [53]. Compelling evidence shows that glycine could rectify vascular dysfunction induced by dietary amino acid imbalance during pregnancy [54].

Oxidative stress can impair the female reproductive physiology by altering the affectivity of antioxidant defense system in humans and animals. There is growing evidence that pregnant sows suffer from elevated levels of oxidative stress in late pregnancy and lactation [5557], due to generation of reactive oxygen species that exceeds the capacity of antioxidant system [58]. Elevated levels of oxidative stress during gestation can impair placental function, including the angiogenesis $[23,59]$ and reproductive performance of sows [23, 60]. Previous study has shown that glycine is the precursor for the synthesis of glutathione, the most-abundant lowmolecular-weight antioxidant in animal tissues, including placenta [61].

Available evidence shows that the amount of glycine synthesized in vivo is insufficient to meet the metabolic demands (i.e., the synthesis of proteins, glutathione, and heme) in humans, pigs, rodents, and other mammals, thus unable to support their maximal growth $[62,63]$. It is worth noting that fetuses and neonates cannot synthesize enough glycine to meet their optimal requirements $[64,65]$, and chronic insufficiency of glycine may result in suboptimal growth, impaired immune responses, and other adverse effects on their health and nutrient metabolism $[66,67]$. A study on the supplementation of $800 \mathrm{mg} / \mathrm{kg} \mathrm{N}$-carbamylglycinate (a derivative of glycine to improve glycine concentrations via the hydrolysis of an amide bond) in the diet of late-gestation 
sows showed that the nutritional levels of glycine and proline in sows were improved, and the litter size and litter weight of live-born piglets were increased [68]. All in all, the multiple beneficial effects of glycine, coupled with its insufficient de novo synthesis, support the notion that, as it cannot be adequately absorbed from the feed, glycine is both a conditionally essential and a functional amino acid for pregnant sows that need sufficient nutrients to support fetal growth [22, 61, 64, 69, 70]. Appropriate supplementation of glycine or its derivatives to pregnant sows may bring greater benefits to actual production, but this information is still limited and needs to be further enriched.

\section{Proline}

Proline serves not only as the building block of proteins, but also as a nitrogenous substrate for endogenous synthesis of arginine, glutamate, and polyamines in mammals [37]. Especially, polyamines (e.g., putrescine, spermidine, and spermine) are key regulators of DNA and protein synthesis, cell proliferation, and differentiation in both the small intestine and placenta of mammals, including pigs $[10,63]$. For porcine placentae, we focus on the function of polyamines in angiogenesis, oxidative stress, protein synthesis, and apoptosis (Fig. 2). Angiogenesis is the physiological process of generating new blood vessels from existing blood vessels in placenta and is the sum of important cellular events including migration, proliferation and growth of endothelial cells [71]. As polyamines can stimulate tissue growth, including placentae, an irreversible inhibitor of ornithine decarboxylase (alpha-difluoromethylornithine, DFMO) was developed to reduce polyamine synthesis at the cellular level [72]. As mentioned above, increased metabolic burdens on sows during late gestation and lactation tend to cause elevated systemic oxidative stress during these important periods $[56,60,73]$. Polyamines are potent antioxidants with cell-protective effects, because they can control the free radicals generated during cellular metabolisms, such as preventing structural and functional damage to DNA by blocking free radicals from binding [44]. Likewise, polyamines can inhibit lipid peroxidation in cell membranes to protect the functionality and structure of lipids in the cell membrane [74]. However, the roles of polyamines in scavenging free radicals remain unclear.

Previous study has indicated that supplementation with putrescine promotes the proliferation of porcine trophectoderm cells by increasing protein synthesis via activation of the mechanistic target of the rapamycin (mTOR) signaling pathway [75]. However, few studies have focused on the effect of putrescine on the reproductive performance of gilts or sows. We suggest that dietary supplementation with or intravenous administration of putrescine could be a potential novel and effective strategy to improve the survival and growth of embryos/fetuses in pigs. Additionally, in porcine parthenote embryos, the combined addition of all the three polyamines (putrescine, spermidine, and spermine) could increase the total cell number and blastocyst formation percentage as well as inhibit apoptosis by partially decreasing the expression of apoptotic genes [69, 76]. These effects of putrescine seem to be transduced through mTOR signaling because inhibiting mTOR with rapamycin prevents the above effects in the pig (Fig. 2) and reduces the level of interferon- $\tau$ induced by putrescine in the sheep conceptus [75, 77]. The abovementioned facts indicate that polyamines have many important functions. One point we must emphasize is that the porcine placenta lacks arginase and arginine decarboxylase, thus unable to synthesize ornithine (the precursor for the synthesis of polyamines) from arginine [78]. Previous study has shown that the substrates for the synthesis of polyamines in the porcine placenta, and novel findings provide that proline oxidase is a rate-controlling enzyme in placental synthesis of polyamines, which converts proline to pyrroline-f-carboxylate, a precursor of both ornithine and polyamines [78]. Indeed, proline provides the bulk of the carbon skeleton and nitrogen in putrescine, spermidine, and spermine [10].

Moreover, compelling evidence from animal studies shows that reduced placental and fetal growth is associated with a reduction in placental proline transport in gestating dams with either naturally occurring or malnutrition-induced growth retardation [37]. During the late gestation period, reduced protein levels in diet may result in insufficient maternal dietary intake of protein and a decrease in the amino acid availability to the fetus, thereby retarding fetal growth $[79,80]$. The amino acid and endogenous protein losses are mainly caused by high losses of glycine, proline, and serine [81]. In the amino acid composition of fetal pigs during the gestation period, glycine and hydroxyproline increased markedly while other amino acids decreased from day 60 to 114 of gestation [82]. However, the activities of proline oxidase, ornithine aminotransferase, and ornithine decarboxylase, as well as proline transport, polyamine synthesis from proline, and polyamine concentrations in placentae, increase markedly between day 20 and 40 of gestation, decline between day 40 and 90 of gestation, and remain at the reduced level from day 110 of gestation [78]. These results indicated that proline ingestion is insufficient during early gestation, which can be well supported by the study of Gonzalez-Anover et al., who demonstrated that the effects of the L-proline supplementation of $14 \mathrm{~g}$ per sow per day in early pregnancy on litter size and birth weight are strongly modulated by the maternal characteristics, such as parity and prolificacy, and that 


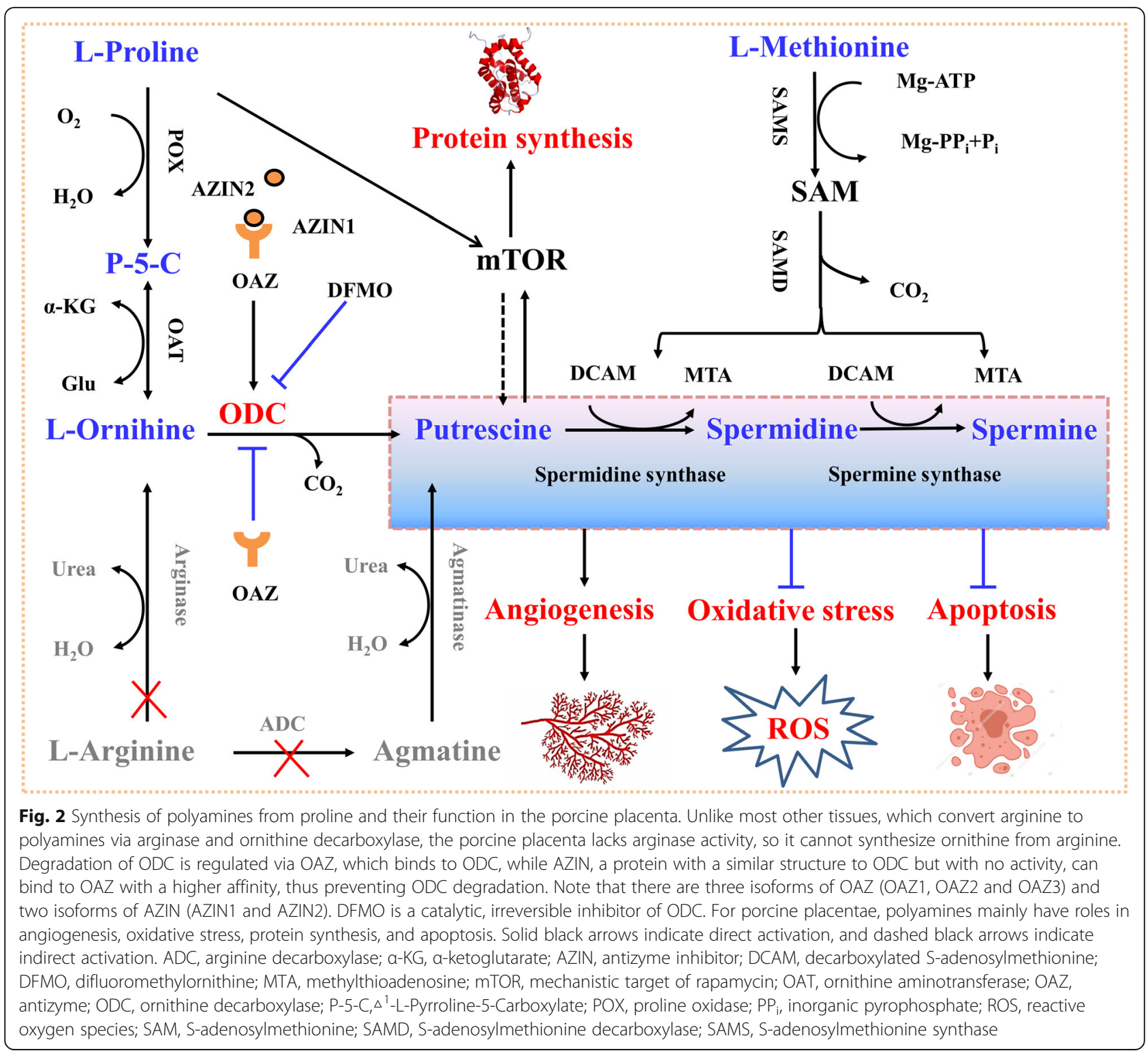

such supplementation can be cost-efficient for the management of females with compromised energy balance, such as sows at second farrowing and highly-prolific primiparous gilts [83]. Recent studies have indicated that maternal L-proline supplementation can improve placental development and fetal survival by enhancing placental nutrient transport, angiogenesis, and protein synthesis in F0 females, and increase the concentrations of polyamines in placental tissues in their F1 females of mice $[84,85]$.

\section{Arginine}

Arginine serves as the physiological precursor for synthesis of protein and other biological molecules, including ornithine, polyamines, proline, glutamine, creatine, and NO [70]. Arginine and its metabolites have versatile functions in cardiovascular, neurological immunological and endocrine systems [86]. Here, we mainly focus on the effect of arginine nutrition on porcine embryonic, placental, and fetal development. In the past three decades, accumulated evidence has indicated that supplementation of arginine improves the reproductive performance in sows (Table 1). Arginine was remodeled as a nutritionally essential amino acid for gestating pigs in the revised version of National Research Council (NRC, 2012). However, previous studies have also reported that dietary arginine showed no or little effect on litter size and could even impair the reproductive performance of gilts and sows [87-89], suggesting that the dose and duration of supplementation should be considered in dietary formulations. Moreover, these results underscore the importance of understanding the basic 
Table 1 Summary of relevant reports on the effects of maternal dietary arginine supplementation on the reproductive performance in swine in the last decade

\begin{tabular}{|c|c|c|c|c|c|c|}
\hline $\begin{array}{l}\text { Supple-mentation } \\
\text { period }\end{array}$ & $\begin{array}{l}\text { Arginine content in } \\
\text { basal diet, \% }\end{array}$ & $\begin{array}{l}\text { Supple-mental } \\
\text { arginine, } \%\end{array}$ & $\begin{array}{l}\text { Litter size of live- } \\
\text { born piglets }\end{array}$ & $\begin{array}{l}\text { Litter weight of live- } \\
\text { born piglets }\end{array}$ & $\begin{array}{l}\text { Placental } \\
\text { weight }\end{array}$ & References \\
\hline d 14-25 & $0.70 \%$ & $0.4 \%$ & 个by 2.2 per litter & - & $\uparrow$ by $34 \%$ & [110] \\
\hline d $14-25$ & $0.70 \%$ & $0.8 \%$ & 个by 1.7 per litter & - & $\uparrow$ by $21 \%$ & [110] \\
\hline d 14-28 & $1.07 \%$ & $0.87 \%$ & $\uparrow$ by 3.7 per litter & $\uparrow$ by $32 \%$ & - & [111] \\
\hline d $1-114$ & $0.72 \%$ & $0.25 \%$ & $\uparrow$ by 0.8 per litter & - & - & [112] \\
\hline d 22-114 & $0.88 \%$ & $0.83 \%$ & $\uparrow$ by 1.1 per litter & $\uparrow$ by $11 \%$ & $\uparrow$ by $16 \%$ & [113] \\
\hline $\begin{array}{l}\text { d } 30-90 \text { or d } 30- \\
114\end{array}$ & $0.73 \%$ & $1 \%$ & $\uparrow$ by 1.6 per litter & $\uparrow$ & Un & [114] \\
\hline d 30-110 & $0.61 \%$ & $0.1 \%$ & $\uparrow$ by 1.1 per litter & - & - & [109] \\
\hline d 70-110 & $0.72 \%$ & $0.28 \%$ & $\uparrow$ by 1.2 per litter & - & - & [115] \\
\hline d 70-110 & $0.72 \%$ & $0.78 \%$ & $\uparrow$ by 1.1 per litter & $\uparrow$ by $12 \%$ & - & [115] \\
\hline d 85-114 & Un & $1 \%$ & $\uparrow$ by 1.4 per litter & - & Un & [116] \\
\hline d 90-114 & Un & $1 \%$ & - & 个by $16 \%$ & Un & [106] \\
\hline
\end{tabular}

Un, undetermined; $\uparrow$, increase; - , no effect

knowledge of reproductive biology, arginine biochemistry and nutrition to improve the reproductive performance of sows.

Generally, pregnant pigs are fed a restricted diet during gestation to avoid excess weight gains and associated farrowing and locomotion issue, and reduce lactational feed intake [90-93]. Thus, dietary provision of arginine for gestating sows is insufficient to meet arginine requirements. In gilts or sows, arginine in circulating blood is derived from diets and endogenous sources, including both de novo synthesis and protein degradation [70]. It is worth noting that only $60 \%$ of dietary arginine enters the portal circulation of pregnant gilts due to the extensive catabolism of arginine by arginase in the small intestine [70]. Additionally, approximately $8 \%$ of arginine in the portal vein is extracted by the liver for protein and urea synthesis [94]. Based on the actual ileal digestibility (85\%) of arginine in a corn-soybean meal-based diet, only $46.92 \%$ of protein-bound arginine in the diet can be used by extra-intestinal and extra-hepatic tissues in gestating gilts [70]. The above-mentioned facts indicate the necessity for the endogenous synthesis of arginine to support embryonic, placental and fetal growth.

Arginine is a common substrate for the synthesis of $\mathrm{NO}$ and polyamines, both of which affect angiogenesis and thus fetal growth. However, the porcine placenta lacks arginase and arginine decarboxylase and therefore cannot synthesize ornithine from arginine [78]. Arginine stimulates placental NO synthesis mainly by enhancing the generation of tetrahydrobiopterin $\left(\mathrm{BH}_{4}\right)$ as an essential cofactor for all NO synthetases (NOSs) [22]. NO synthesis and arginine transport in cultured placentae showed a 6.3- and 6.7-fold increase between day 20 and 40 of gestation, respectively, followed by a decrease, suggesting the rapid decrease of arginine and $\mathrm{NO}$ to support angiogenesis in gestating swine [95]. Of particular note estrogen and progesterone enhanced the constitutive and inducible NOS activities as well as the $\mathrm{BH}_{4}$ concentration in the porcine placenta, thus playing a synergistic role in promoting placental $\mathrm{NO}$ synthesis [10]. The arginine-NO pathway is an important regulator of vascular development. At the endothelial interface, NO regulates critical mediators of angiogenesis, including the vascular endothelial growth factor (VEGF) (e.g., placental growth factor, its receptor fms-like tyrosine sinase-1) and angiopoietin-tunica interna endothelial cell kinase 2 (Tie-2) protein families (e.g., angiopoietin-1, angiopoietin-2 and their receptor). The induction of angiogenesis by angiopoietin and VEGF signaling is dependent on the protein-kinase-mediated downstream activation of endothelial NOS in the endothelium [96], and the consequent production of $\mathrm{NO}$ from arginine $[97,98]$. Additionally, NO diffuses to the underlying vascular smooth muscle cells to act on guanosine and produce cyclic guanosine monophosphate via guanylate cyclase, which is capable of dilating blood vessels (Fig. 3) [99]. Additionally, arginine activates the mTOR cell signaling pathway to stimulate protein synthesis in the placenta, uterus, and fetus [100]. Collectively, the available evidence implicates the dysregulation of arginine-NO biogenesis in a range of vascular pathologies in humans and pigs $[70,101]$.

It has been widely accepted that arginine promotes the growth of skeletal muscle and reduces the accretion of white adipose tissue [102]. Apart from arginine play a role in angiogenesis of placental development, recent years have witnessed increasing interest in its effect on fetal myofiber formation during gestation as evidenced by a study reporting that arginine supplementation to sows during early gestation obviously enhanced not only 


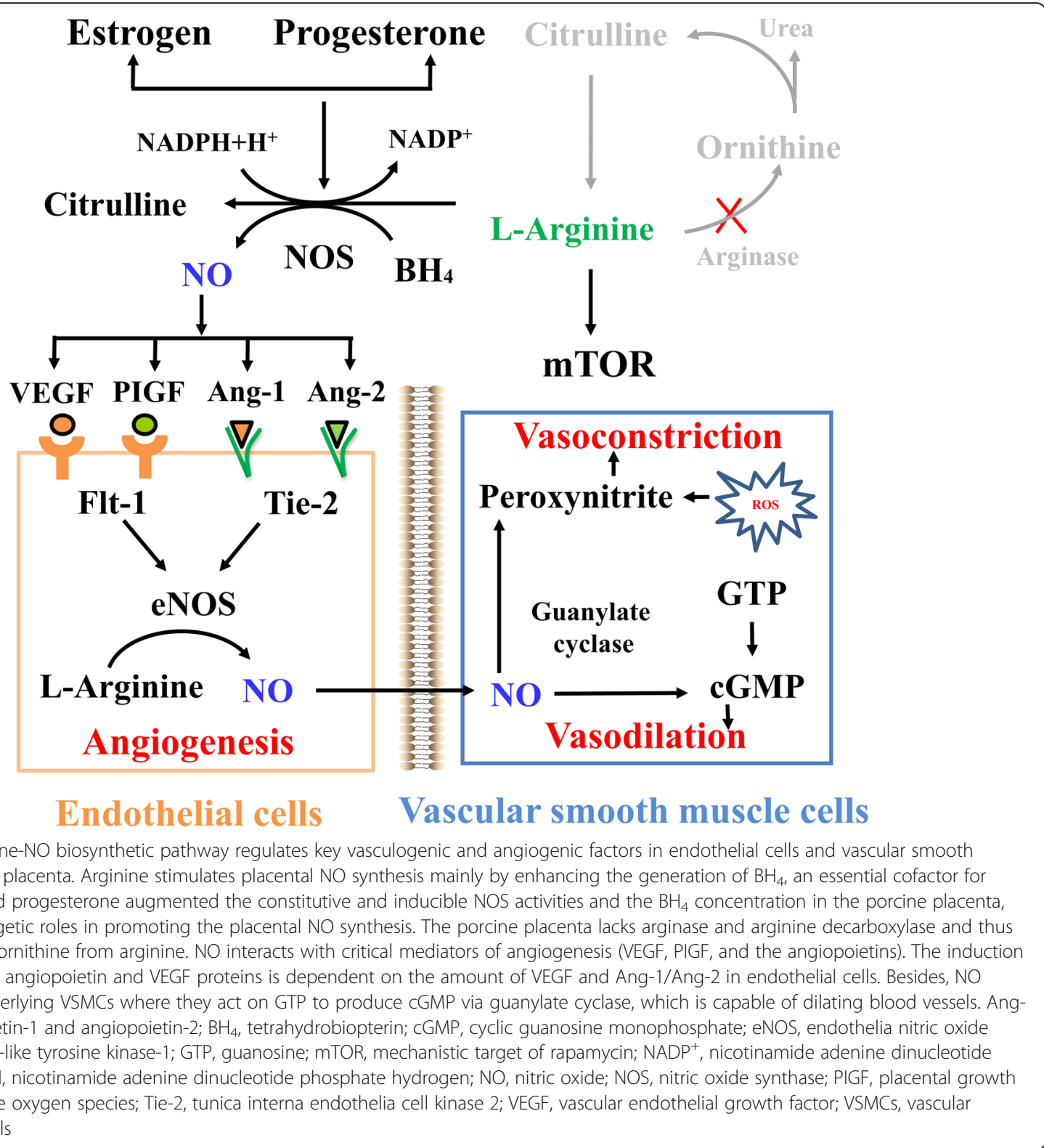

prenatal myofiber hyperplasia but also hypertrophy [103]. In contrast, decreased availability of both arginine and $\mathrm{NO}$ increases the proliferation of preadipocytes and adipocytes in IUGR fetuses. Collectively, arginine regulates nutrient partitioning to promote skeletal muscle growth over white-fat accretion during gestation [22].

As an endogenous activator of arginine, Ncarbamylglutamate (NCG) also has a similar effect on fetal growth and placental development. NCG, a safe and metabolically stable functional analog of $\mathrm{N}$ acetylglutamate, can activate the key enzyme (carbamylphosphate synthetase-1) of the arginine-synthetic pathway and increase the endogenous synthesis of arginine $[104,105]$. Studies have shown that both arginine and NCG can increase litter size and fetal birth weight of sows, which may be related to the up-regulation of placental angiogenesis [106], and similar results have been reported in pregnant ewes [107]. The results in pregnant rats confirm that NCG can effectively increase the concentration of arginine family amino acids in maternal circulation and uterine fluid, thus improving the pregnancy outcome [108].

Although its beneficial effect on pregnant sows has been confirmed by a large number of experiments, the supplementation of $0.8-1 \%$ arginine to the diet was reported to greatly increase the feed cost due to the high price of arginine, thereby restricting its wide use [109]. According to the summary of Table 1, low-dose arginine supplementation (about $0.1-0.4 \%$ ) in sow diets during pregnancy can also promote pregnancy outcomes. 
Moreover, compared with the direct addition of arginine to the diet of sows, supplementation of NCG at the arginine level of $1 / 10$ can have similar effects on their reproductive performance [106], thus reducing the high costs of direct supplementation of arginine to the diets of pregnant sows. In conclusion, the research and development of dietary supplementation strategies with low doses of arginine or NCG for pregnant sows will be a feasible way to improve the arginine metabolism, placental development, and fetal growth of sows.

\section{Conclusion}

In the last decade, the selection for high prolificacy in modern sow herds has led to a marked increase in litter size. The consistent outcomes of this strategy are an increase of the embryonic losses during early gestation and the number of less vital and less mature low-birthweight piglets at farrowing. The important contributors to this result seem to be aberrant placental development and functional impairment (deficits in vasculature) in early gestation and inadequate uterine capacity at all periods of gestation. Among nutrients, amino acids play the most important role in placental growth because they are absolutely required for synthesis of sufficient proteins to support the proliferation of trophectoderm and endothelial cells. Moreover, amino acids are not only the building blocks of proteins in cells, but also the precursors for synthesis of nitrogenous substances (e.g., $\mathrm{NO}$, polyamines and glutathione) essential for placental growth and angiogenesis, conceptus development or scavenging free radicals to prevent placental oxidative damage. The requirements of amino acids in placentae differ markedly as gestation advances, but the amount of amino acids, especially glycine, proline, and arginine, is reduced due to the widespread practice of restricted feeding programs in sows during the entire gestation period to prevent excessive maternal body gains. Simply increasing the total crude protein content in the maternal diet is not an effective option because its oxidation generates high levels of ammonia and is extremely toxic to embryos and fetuses. Thus, adding specific amino acids that are deficient in the dietary supply is an attractive strategy to enhance placental growth and function, which in turn promotes fetal growth and development. As mentioned earlier, adding glycine, proline, arginine and their derivatives or endogenous synthesis promoters in the diets of pregnant sows will potentially promote the sow's reproductive performance, fetal growth, and placental development. However, there is still a paucity of information on the effects of dietary functional amino acids on placental and conceptus development in swine except for arginine. This review has laid a theoretical basis for facilitating the translation of the basic research on glycine and proline biochemistry and physiology into feeding practice, and provided a reference for the nutritional strategy to improve the reproductive performance of sows.

\section{Abbreviations}

$\mathrm{BH}_{4}$ : Tetrahydrobiopterin; DFMO: Alpha-difluoromethylornithine; IUGR: Intrauterine growth retardation; mTOR: Mechanistic target of the rapamycin; NCG: N-carbamylglutamate; NO: Nitric oxide; NOSs: NO synthetases; Tie-2: Tunica interna endothelia cell kinase 2; VEGF: Vascular endothelial growth factor

\section{Acknowledgements}

The authors would like to thank the China Scholarship Council (201907630006) for assistance.

\section{Authors' contributions}

$\mathrm{CT}$ and $\mathrm{YY}$ conceived the review. $\mathrm{CT}$ and $\mathrm{ZH}$ wrote the review. All the authors have read, revised and approved the final manuscript.

\section{Funding}

The present work was jointly supported by the National Key R\&D Program of China (2021YFD1300401), National Natural Science Foundation of China (31902165) and Natural Science Foundation of Guangdong Province (2021A1515012116)

Availability of data and materials Not applicable.

\section{Declarations}

\section{Competing of interest}

There were no conflicts of interest.

Ethics approval and consent to participate

Not applicable.

Consent for publication

Not applicable.

Received: 5 October 2021 Accepted: 9 January 2022

Published online: 02 March 2022

References

1. Lewis $C R G$, Hermesch S. Genetic parameters and phenotypic trends in the mean and variability of number of stillborn piglets and changes in their relationships with litter size and gestation length. Anim Prod Sci. 2013;53(5): 395-402. https://doi.org/10.1071/An12202.

2. Tokach MD, Menegat MB, Gourley KM, Goodband RD. Review: nutrient requirements of the modern high-producing lactating sow, with an emphasis on amino acid requirements. Animal. 2019;13(12):2967-77. https:// doi.org/10.1017/S1751731119001253.

3. Geisert RD, Sutvosky P, Lucy MC, Bartol FF, Meyer AE. Reproductive physiology of swine. In: Bazer FW, Lamb GC, Wu G, editors. Animal Agriculture. London: Academic Press; 2020. p. 263-81. https://doi.org/10.101 6/B978-0-12-817052-6.00015-X.

4. Gonzalez-Anover P, Encinas T, Torres-Rovira L, Pallares P, Munoz-Frutos J, Gomez-Izquierdo E, et al. Ovulation rate, embryo mortality and intrauterine growth retardation in obese swine with gene polymorphisms for leptin and melanocortin receptors. Theriogenology. 2011;75(1):34-41. https://doi.org/1 0.1016/j.theriogenology.2010.07.009.

5. lida R, Yatabe Y, Pieiro C, Koketsu Y. Nurse sows' reproductive performance in different parities and lifetime productivity in Spain. J Agric Sci. 2019; 11(10):29. https://doi.org/10.5539/jas.v11n10p29.

6. Yang YY, Deng M, Chen JZ, Zhao XC, Xiao KL, He WL, et al. Starch supplementation improves the reproductive performance of sows in different glucose tolerance status. Anim Nutr. 2021;7(4):1231-41. https://doi. org/10.1016/j.aninu.2021.03.010.

7. Kridli RT, Khalaj K, Bidarimath M, Tayade C. Placentation, maternal-fetal interface, and conceptus loss in swine. Theriogenology. 2016;85(1):135-44. https://doi.org/10.1016/j.theriogenology.2015.08.001. 
8. Wu MC, Hentzel MD, Dziuk PJ. Relationships between uterine length and number of fetuses and prenatal mortality in pigs. J Anim Sci. 1987;65(3): 762-70. https://doi.org/10.2527/jas1987.653762x.

9. Wilson ME, Biensen NJ, Ford SP. Novel insight into the control of litter size in pigs, using placental efficiency as a selection tool. J Anim Sci. 1999;77(7): 1654-8. https://doi.org/10.2527/1999.7771654x.

10. Wu GY, Bazer FW, Johnson GA, Herring C, Seo H, Dai ZL, et al. Functional amino acids in the development of the pig placenta. Mol Reprod Dev. 2017; 84(9):870-82. https://doi.org/10.1002/mrd.22809.

11. Wu G, Bazer FW, Wallace JM, Spencer TE. Board-invited review: intrauterine growth retardation: implications for the animal sciences. J Anim Sci. 2006; 84(9):2316-37. https://doi.org/10.2527/jas.2006-156.

12. Kobek-Kjeldager C, Moustsen VA, Theil PK, Pedersen LJ. Effect of litter size, milk replacer and housing on production results of hyper-prolific sows. Animal. 2020;14(4):824-33. https://doi.org/10.1017/S175173111900260X.

13. Bazer FW, Burghardt RC, Johnson GA, Spencer TE, Wu GY. Interferons and progesterone for establishment and maintenance of pregnancy: interactions among novel cell signaling pathways. Reprod Biol. 2008;8(3):179-211. https://doi.org/10.1016/s1642-431x(12)60012-6

14. Yuan $T L$, Zhu YH, Shi M, Li TT, Li N, Wu GY, et al. Within-litter variation in birth weight: impact of nutritional status in the sow. J Zhejiang Univ Sci B. 2015;16(6):417-35. https://doi.org/10.1631/jzus.B1500010

15. Bazer FW, Johnson GA. Pig blastocyst-uterine interactions. Differentiation. 2014;87(1-2):52-65. https://doi.org/10.1016/j.diff.2013.11.005.

16. Hao Y, Lai L, Mao J, Im GS, Bonk A, Prather RS. Apoptosis and in vitro development of preimplantation porcine embryos derived in vitro or by nuclear transfer. Biol Reprod. 2003;69(2):501-7. https:/doi.org/10.1095/ biolreprod.103.016170.

17. Hu C, Yang Y, Chen M, Hao X, Wang S, Yang L, et al. A maternal high-fat/ low-fiber diet impairs glucose tolerance and induces the formation of glycolytic muscle fibers in neonatal offspring. Eur J Nutr. 2021;60(5):2709-18. https://doi.org/10.1007/s00394-020-02461-4.

18. Vallet JL, Freking BA, Miles JR. Effect of empty uterine space on birth intervals and fetal and placental development in pigs. Anim Reprod Sci. 2011;125(1-4):158-64. https://doi.org/10.1016/j.anireprosci.2011.03.006.

19. Ford SP. Embryonic and fetal development in different genotypes in pigs. J Reprod Fertil Suppl. 1997;52:165-76.

20. Wilson ME, Biensen NJ, Youngs CR, Ford SP. Development of Meishan and Yorkshire littermate conceptuses in either a Meishan or Yorkshire uterine environment to day 90 of gestation and to term. Biol Reprod. 1998;58(4): 905-10. https://doi.org/10.1095/biolreprod58.4.905.

21. Croy BA, Wessels J, Linton N, Tayade C. Comparison of immune cell recruitment and function in endometrium during development of epitheliochorial (pig) and hemochorial (mouse and human) placentas. Placenta. 2009;30:S26-31. https://doi.org/10.1016/j.placenta.2008.09.019.

22. Wu GY. Functional amino acids in growth, reproduction, and health. Adv Nutr. 2010;1(1):31-7. https://doi.org/10.3945/an.110.1008.

23. Hu CJ, Yang YY, Li JY, Wang H, Cheng CH, Yang LF, et al. Maternal dietinduced obesity compromises oxidative stress status and angiogenesis in the porcine placenta by upregulating Nox2 expression. Oxidative Med Cell Longev. 2019;2019:2481592. https://doi.org/10.1155/2019/2481592.

24. Bidarimath $M$, Tayade C. Pregnancy and spontaneous fetal loss: a pig perspective. Mol Reprod Dev. 2017;84(9):856-69. https://doi.org/10.1002/mrd.22847.

25. Hu C, Wu Z, Huang Z, Hao X, Wang S, Deng J, et al. Nox2 impairs VEGF-Ainduced angiogenesis in placenta via mitochondrial ROS-STAT3 pathway. Redox Biol. 2021;45:102051. https://doi.org/10.1016/j.redox.2021.102051.

26. Bazer FW, Thatcher WW, Martinat-Botte F, Terqui M. Conceptus development in large white and prolific Chinese Meishan pigs. J Reprod Fertil. 1988;84(1):37-42. https://doi.org/10.1530/jrf.0.0840037.

27. Spencer TA, Chai H, Fu W, Ramaswami G, Cox MW, Conklin BS, et al. Estrogen blocks homocysteine-induced endothelial dysfunction in porcine coronary arteries 1,2. J Surg Res. 2004;118(1):83-90. https://doi.org/10.1016/j. jss.2004.01.021.

28. Bazer FW, Vallet JL, Roberts RM, Sharp DC, Thatcher WW. Role of conceptus secretory products in establishment of pregnancy. J Reprod Fertil. 1986; 76(2):841-50. https://doi.org/10.1530/jrf.0.0760841.

29. Keys $J$, King GJ. Microscopic examination of porcine conceptus-maternal interface between days 10 and 19 of pregnancy. Am J Anat. 1990;188(3): 221-38. https://doi.org/10.1002/aja.1001880302.

30. Bazer FW, First NL. Pregnancy and parturition. J Anim Sci. 1983:57(Suppl 2): 425-60. https://doi.org/10.2527/animalsci1983.57Supplement_2425x.
31. Wooding FBP, Fowden AL. Nutrient transfer across the equine placenta: correlation of structure and function. Equine Vet J. 2006;38(2):175-83. https://doi.org/10.2746/042516406776563341.

32. Dantzer $V$. Electron microscopy of the initial stages of placentation in the pig. Anat Embryol (Berl). 1985;172(3):281-93. https://doi.org/10.1007/BF00318976.

33. Carter AM, Enders AC. The evolution of epitheliochorial placentation. Annu Rev Anim Biosci. 2013;1(1):443-67. https://doi.org/10.1146/annurev-animal031412-103653.

34. Knight JW, Bazer FW, Thatcher WW, Franke DE, Wallace HD. Conceptus development in intact and unilaterally hysterectomized-ovariectomized gilts: interrelations among hormonal status, placental development, fetal fluids and fetal growth. J Anim Sci. 1977;44(4):620-37. https://doi.org/10.2527/jas1 977.444620x.

35. Bazer FW, Brace RA. Allantoic fluid: regulation of volume and composition. Reproductive and perinatal medicine. 1989;11:135-55.

36. Jang $Y D, M a Y L$, Payne RL, Lindemann MD. Amino acid composition of fetus, placenta, and uterus in gilts throughout gestation. J Anim Sci. 2017; 95(10):4448-61. https://doi.org/10.2527/jas2017.1836.

37. Wu G, Bazer FW, Datta S, Johnson GA, Li P, Satterfield MC, et al. Proline metabolism in the conceptus: implications for fetal growth and development. Amino Acids. 2008;35(4):691-702. https://doi.org/10.1007/ s00726-008-0052-7.

38. McPherson R, Ji F, Wu G, Blanton J Jr, Kim S. Growth and compositional changes of fetal tissues in pigs. J Anim Sci. 2004;82(9):2534-40. https://doi. org/10.2527/2004.8292534x.

39. Huang Z, Huang S, Song T, Yin Y, Tan C. Placental angiogenesis in mammals: a review of the regulatory effects of signaling pathways and functional nutrients. Adv Nutr. 2021;12(6):2415-34. https://doi.org/10.1093/a dvances/nmab070.

40. Enders AC, Blankenship TN. Comparative placental structure. Adv Drug Deliv Rev. 1999;38(1):3-15. https://doi.org/10.1016/S0169-409X(99)00003-4.

41. Ashdown RR, Marrable AW. Adherence and fusion between the extremities of adjacent embryonic sacs in the pig. J Anat. 1967;101(Pt 2):269-75.

42. Sterzl J, Rejnek J, Travnicek J. Impermeability of pig placenta for antibodies. Folia Microbiol (Praha). 1966;11(1):7-10. https://doi.org/10.1007/BF02877148.

43. Beck F. Comparative placental morphology and function. Environ Health Perspect. 1976;18:5-12. https://doi.org/10.1289/ehp.76185.

44. Rider JE, Hacker A, Mackintosh CA, Pegg AE, Woster PM, Casero RA. Spermine and spermidine mediate protection against oxidative damage caused by hydrogen peroxide. Amino Acids. 2007;33(2):231-40. https://doi. org/10.1007/s00726-007-0513-4.

45. Huang S, Wu Z, Huang Z, Hao X, Zhang L, Hu C, et al. Maternal supply of cysteamine alleviates oxidative stress and enhances angiogenesis in porcine placenta. J Anim Sci Biotechnol. 2021;12:91. https://doi.org/10.1186/s40104021-00609-8.

46. Self JT, Spencer TE, Johnson GA, Hu J, Bazer FW, Wu G. Glutamine synthesis in the developing porcine placenta. Biol Reprod. 2004;70(5):1444-51. https:// doi.org/10.1095/biolreprod.103.025486.

47. Xia P, Rutledge J, Armstrong DT. Expression of glycine cleavage system and effect of glycine on in vitro maturation, fertilization and early embryonic development in pigs. Anim Reprod Sci. 1995;38(1):155-165. https://doi.org/1 0.1016/0378-4320(94)01345-M.

48. Bassler KH. Enzymatic effects of folic acid and vitamin B12. Int J Vitam Nutr Res. 1997;67(5):385-8.

49. Kikuchi $\mathrm{G}$. The glycine cleavage system: composition, reaction mechanism, and physiological significance. Mol Cell Biochem. 1973;1(2):169-87. https:// doi.org/10.1007/BF01659328.

50. Iritani A, Sato E, Nishikawa Y. Secretion rates and chemical composition of oviduct and uterine fluids in sows. J Anim Sci. 1974;39(3):582-8. https://doi. org/10.2527/jas1974.393582x.

51. Wu G, Bazer FW, Tou W. Developmental changes of free amino acid concentrations in fetal fluids of pigs. J Nutr. 1995;125(11):2859-68. https:// doi.org/10.1093/jn/125.11.2859.

52. Guay F, Matte JJ, Girard CL, Palin MF, Giguiere A, Laforest JP. Effect of folic acid and glycine supplementation on embryo development and folate metabolism during early pregnancy in pigs. J Anim Sci. 2002;80(8):2134-43. https://doi.org/10.2527/2002.8082134x.

53. Jackson AA, Dunn RL, Marchand MC, Langley-Evans SC. Increased systolic blood pressure in rats induced by a maternal low-protein diet is reversed by dietary supplementation with glycine. Clin Sci (Lond). 2002;103(6):633-9. https://doi.org/10.1042/cs1030633. 
54. Brawley L, Torrens C, Anthony FW, Itoh S, Wheeler T, Jackson AA, et al. Glycine rectifies vascular dysfunction induced by dietary protein imbalance during pregnancy. J Physiol. 2004;554(2):497-504. https://doi.org/10.1113/ jphysiol.2003.052068.

55. Wang H, Hu C, Cheng C, Cui J, Ji Y, Hao X, et al. Unraveling the association of fecal microbiota and oxidative stress with stillbirth rate of sows. Theriogenology. 2019;136:131-7. https://doi.org/10.1016/j.theriogenology.2 019.06 .028$.

56. Tan CQ, Wei HK, Sun HQ, Ao JT, Long G, Jiang SW, et al. Effects of dietary supplementation of oregano essential oil to sows on oxidative stress status, lactation feed intake of sows, and piglet performance. Biomed Res Int. 2015; 2015:525218. https://doi.org/10.1155/2015/525218.

57. Tan CQ, Ji YC, Zhao XC, Xin ZQ, Li JY, Huang SB, et al. Effects of dietary supplementation of nucleotides from late gestation to lactation on the performance and oxidative stress status of sows and their offspring. Anim Nutr. 2021;7(1):111-8. https://doi.org/10.1016/j.aninu.2020.10.004.

58. Tan CQ, Li JY, Ji YC, Yang YY, Zhao XC, Chen MX, et al. Effects of dietary supplementation of different amounts of yeast extract on oxidative stress, milk components, and productive performance of sows. Anim Feed Sci Technol. 2021;274:114648. https://doi.org/10.1016/j.anifeedsci.2020.114648.

59. Hu CJ, Yang YY, Deng M, Yang LF, Shu G, Jiang QY, et al. Placentae for low birth weight piglets are vulnerable to oxidative stress, mitochondrial dysfunction, and impaired angiogenesis. Oxidative Med Cell Longev. 2020; 2020:8715412. https://doi.org/10.1155/2020/8715412

60. Tan CQ, Wei HK, Ao JT, Long G, Peng J. Inclusion of konjac flour in the gestation diet changes the gut microbiota, alleviates oxidative stress, and improves insulin sensitivity in sows. Appl Environ Microbiol. 2016;82(19): 5899-909. https://doi.org/10.1128/Aem.01374-16.

61. Wu G, Wu Z, Dai Z, Yang Y, Wang W, Liu C, et al. Dietary requirements of "nutritionally non-essential amino acids" by animals and humans. Amino Acids. 2013;44(4):1107-13. https://doi.org/10.1007/s00726-012-1444-2.

62. Razak MA, Begum PS, Viswanath B, Rajagopal S. Multifarious beneficial effect of nonessential amino acid, glycine: a review. Oxidative Med Cell Longev. 2017;2017:1-8. https://doi.org/10.1155/2017/1716701

63. Li P, Wu GY. Roles of dietary glycine, proline, and hydroxyproline in collagen synthesis and animal growth. Amino Acids. 2017;50(1):29-38. https://doi. org/10.1007/s00726-017-2490-6.

64. Wang WW, Wu ZL, Dai ZL, Yang Y, Wang JJ, Wu GY. Glycine metabolism in animals and humans: implications for nutrition and health. Amino Acids. 2013:45(3):463-77. https://doi.org/10.1007/s00726-013-1493-1.

65. Regnault TRH, de Vrijer B, Battaglia FC. Transport and metabolism of amino acids in placenta. Endocrine. 2002;19(1):23-41. https://doi.org/10.1385/ ENDO:19:1:23.

66. Ren W, Rajendran R, Zhao Y, Tan B, Wu G, Bazer FW, et al. Amino acids as mediators of metabolic cross talk between host and pathogen. Front Immunol. 2018;9:319. https://doi.org/10.3389/fimmu.2018.00319.

67. Gundersen $Y$, Vaagenes P, Os Q, Pillgram-Larsen J, Sundnes KO, Opstad PK. Capacity of glycine to modulate early inflammatory disturbances after serious gunshot injuries in the pig. Scand J Clin Lab Invest. 2007;67(2):14353. https://doi.org/10.1080/00365510600995226.

68. Wan D, Li Y, Li G, Wu X, Zhang D, Shu X. Dietary supplementation with Ncarbamylglycinate (CGly) improved feed source proline absorption and reproductive performance in sows. Food Funct. 2020;11(4):3126-33. https:// doi.org/10.1039/c9fo01940e.

69. Fenelon JC, Banerjee A, Lefevre P, Gratian F, Murphy BD. Polyaminemediated effects of prolactin dictate emergence from mink obligate embryonic diapause. Biol Reprod. 2016;95(1):6. https://doi.org/10.1095/ biolreprod.116.139204

70. Wu GY, Bazer FW, Satterfield MC, Li XL, Wang XQ, Johnson GA, et al. Impacts of arginine nutrition on embryonic and fetal development in mammals. Amino Acids. 2013;45(2):241-56. https://doi.org/10.1007/s00726013-1515-z.

71. Jasnis MA, Klein S, Monte M, Davel L, Sacerdote de Lustig E, Algranati ID. Polyamines prevent DFMO-mediated inhibition of angiogenesis. Cancer Lett. 1994;79(1):39-43. https://doi.org/10.1016/0304-3835(94)90060-4.

72. Fenelon JC, Murphy BD. New functions for old factors: the role of polyamines during the establishment of pregnancy. Reprod Fertil Dev. 2019; 31(7):1228-39. https://doi.org/10.1071/RD18235.

73. Yang $Y Y, H u C J$, Zhao XC, Xiao KL, Deng M, Zhang L, et al. Dietary energy sources during late gestation and lactation of sows: effects on performance, glucolipid metabolism, oxidative status of sows, and their offspring. J Anim Sci. 2019;97(11):4608-18. https://doi.org/10.1093/jas/skz297.

74. Lenis YY, Elmetwally MA, Maldonado-Estrada JG, Bazer FW. Physiological importance of polyamines. Zygote. 2017;25(3):244-55. https://doi.org/10.101 7/S0967199417000120

75. Kong XF, Wang XQ, Yin YL, Li XL, Gao HJ, Bazer FW, et al. Putrescine stimulates the mTOR signaling pathway and protein synthesis in porcine trophectoderm cells. Biol Reprod. 2014;91(5):106. https://doi.org/10.1095/ biolreprod.113.113977

76. Cui XS, Kim NH. Polyamines inhibit apoptosis in porcine parthenotes developing in vitro. Mol Reprod Dev. 2005;70(4):471-7. https://doi.org/10.1 002/mrd.20228.

77. Wang XQ, Burghardt RC, Romero JJ, Hansen TR, Wu GY, Bazer FW. Functional roles of arginine during the peri-implantation period of pregnancy. III. arginine stimulates proliferation and interferon tau production by ovine trophectoderm cells via nitric oxide and polyamineTSC2-MTOR signaling pathways. Biol Reprod. 2015;92(3):75. https://doi.org/1 0.1095/biolreprod.114.125989.

78. Wu GY, Bazer FW, Hu JB, Johnson GA, Spencer TE. Polyamine synthesis from proline in the developing porcine placenta. Biol Reprod. 2005;72(4):842-50. https://doi.org/10.1095/biolreprod.104.036293.

79. Wu G, Pond WG, Ott T, Bazer FW. Maternal dietary protein deficiency decreases amino acid concentrations in fetal plasma and allantoic fluid of pigs. J Nutr. 1998;128(5):894-902. https://doi.org/10.1093/jn/128.5.894.

80. Hu CJ, Jin P, Yang YY, Yang LF, Zhang ZW, Zhang L, et al. Effects of different maternal feeding strategies from day 1 to day 85 of gestation on glucose tolerance and muscle development in both low and normal birth weight piglets. J Sci Food Agric. 2020;100(15):5403-11. https://doi.org/10.1002/jsfa.1 0591.

81. Stein HH, Trottier NL, Bellaver C, Easter RA. The effect of feeding level and physiological status on total flow and amino acid composition of endogenous protein at the distal ileum in swine. J Anim Sci. 1999;77(5): 1180-7. https://doi.org/10.2527/1999.7751180x.

82. Wu G, Ott TL, Knabe DA, Bazer FW. Amino acid composition of the fetal pig J Nutr. 1999;129(5):1031-8. https://doi.org/10.1093/jn/129.5.1031.

83. Gonzalez-Anover P, Gonzalez-Bulnes A. Maternal age modulates the effects of early-pregnancy L-proline supplementation on the birth-weight of piglets. Anim Reprod Sci. 2017;181:63-8. https://doi.org/10.1016/j.a nireprosci.2017.03.016

84. Liu N, Dai Z, Zhang Y, Chen J, Yang Y, Wu G, et al. Maternal L-proline supplementation enhances fetal survival, placental development, and nutrient transport in micedagger. Biol Reprod. 2019;100(4):1073-81. https:// doi.org/10.1093/biolre/ioy240.

85. Liu N, Dai Z, Zhang Y, Jia H, Chen J, Sun S, et al. Maternal I-proline supplementation during gestation alters amino acid and polyamine metabolism in the first generation female offspring of C57BL/6J mice. Amino Acids. 2019;51(5):805-11. https://doi.org/10.1007/s00726-019-02717-2.

86. Wu GY. Amino acids: metabolism, functions, and nutrition. Amino Acids. 2009;37(1):1-17. https://doi.org/10.1007/s00726-009-0269-0.

87. Hines EA, Romoser MR, Kiefer ZE, Keating AF, Baumgard LH, Niemi J, et al. The impact of dietary supplementation of arginine during gestation in a commercial swine herd: I. gilt reproductive performance. J Anim Sci. 2019; 97(9):3617-25. https://doi.org/10.1093/jas/skz233.

88. Zier-Rush C, Kuntzman A, Schmidt T, Usry J, McKilligan D, Boyd R. Arginine supplement in early and late pregnant sows did not improve litter size or birth weight. J Anim Sci. 2012;90(Suppl. 2):34.

89. Greiner L, Usry J, Neill C, Williams N, Connor J, Allee G. The evaluation of supplemental L-arginine during gestation on sow reproductive performance. J Anim Sci. 2012;90(Suppl 2):33-4.

90. Tan CQ, Sun HQ, Wei HK, Tan JJ, Long G, Jiang SW, et al. Effects of soluble fiber inclusion in gestation diets with varying fermentation characteristics on lactational feed intake of sows over two successive parities. Animal. 2018;12(7):1388-95. https://doi.org/10.1017/S1751731117003019.

91. Tan CQ, Wei HK, Sun HQ, Long G, Ao JT, Jiang SW, et al. Effects of supplementing sow diets during two gestations with konjac flour and Saccharomyces boulardii on constipation in peripartal period, lactation feed intake and piglet performance. Anim Feed Sci Technol. 2015;210:254-62. https://doi.org/10.1016/j.anifeedsci.2015.10.013.

92. Meunier-Salaün MC, Edwards SA, Robert S. Effect of dietary fibre on the behaviour and health of the restricted fed sow. Anim Feed Sci Technol 2001;90(1):53-69. https://doi.org/10.1016/S0377-8401(01)00196-1. 
93. Deng J, Cheng C, Yu H, Huang S, Hao X, Chen J, et al. Inclusion of wheat aleurone in gestation diets improves postprandial satiety, stress status and stillbirth rate of sows. Anim Nutr. 2021;7(2):412-20. https://doi.org/10.1016/ j.aninu.2020.06.015

94. Wu GY, Bazer FW, Cudd TA, Jobgen WS, Kim SW, Lassala A, et al. Pharmacokinetics and safety of arginine supplementation in animals. J Nutr. 2007;137(6):1673s-80s. https://doi.org/10.1093/jn/137.6.1673S.

95. Vonnahme KA, Ford SP. Placental vascular endothelial growth factor receptor system mRNA expression in pigs selected for placental efficiency. J Physiol. 2004;554(1):194-201. https://doi.org/10.1113/jphysiol.2003.055061.

96. Weckman AM, McDonald CR, Baxter J-AB, Fawzi WW, Conroy AL, Kain KC. Perspective: L-arginine and L-citrulline supplementation in pregnancy: a potential strategy to improve birth outcomes in low-resource settings. Adv Nutr. 2019;10(5):765-77. https://doi.org/10.1093/advances/nmz015.

97. Krause BJ, Hanson MA, Casanello P. Role of nitric oxide in placental vascular development and function. Placenta. 2011;32(11):797-805. https://doi.org/1 0.1016/j.placenta.2011.06.025.

98. Rossmanith WG, Hoffmeister U, Wolfahrt S, Kleine B, McLean M, Jacobs RA, et al. Expression and functional analysis of endothelial nitric oxide synthase (eNOS) in human placenta. Mol Hum Reprod. 1999;5(5):487-94. https://doi. org/10.1093/molehr/5.5.487.

99. Wang $Y$, Zhao S. Integrated systems physiology: from molecules to function to disease. Edtion ed. Vascular biology of the placenta. San Rafael (CA): Morgan \& Claypool Life Sciences. 2010:1-98.

100. Kong XF, Tan B, Yin YL, Gao HJ, Li XL, Jaeger LA, et al. L-arginine stimulates the mTOR signaling pathway and protein synthesis in porcine trophectoderm cells. Biol Reprod. 2012;23(9):1178-83. https://doi.org/10.101 6/j.jnutbio.2011.06.012.

101. Boger RH, Bode-Boger SM, Frolich JC. The L-arginine-nitric oxide pathway: role in atherosclerosis and therapeutic implications. Atherosclerosis. 1996; 127(1):1-11. https://doi.org/10.1016/S0021-9150(96)05953-9.

102. Nall JL, Wu G, Kim KH, Choi CW, Smith SB. Dietary supplementation of Larginine and conjugated linoleic acid reduces retroperitoneal fat mass and increases lean body mass in rats. J Nutr. 2009;139(7):1279-85. https://doi. org/10.3945/jn.108.102301.

103. Madsen JG, Pardo C, Kreuzer M, Bee G. Impact of dietary L-arginine supply during early gestation on myofiber development in newborn pigs exposed to intra-uterine crowding. J Anim Sci Biotechnol. 2017;8:58. https://doi.org/1 0.1186/s40104-017-0188-y.

104. Wu G, Knabe DA, Kim SW. Arginine nutrition in neonatal pigs. J Nutr. 2004; 134(10 Suppl):2783S-2790S; discussion 96S-97S. https://doi.org/10.1093/ jn/134.10.2783S.

105. Frank JW, Escobar J, Nguyen HV, Jobgen SC, Jobgen WS, Davis TA, et al. Oral N-carbamylglutamate supplementation increases protein synthesis in skeletal muscle of piglets. J Nutr. 2007;137(2):315-9. https://doi.org/10.1093/ jn/137.2.315.

106. Wu X, Yin YL, Liu YQ, Liu XD, Liu ZQ, Li TJ, et al. Effect of dietary arginine and $\mathrm{N}$-carbamoylglutamate supplementation on reproduction and gene expression of eNOS, VEGFA and PIGF1 in placenta in late pregnancy of sows. Anim Reprod Sci. 2012;132(3-4):187-92. https://doi.org/10.1016/j.a nireprosci.2012.05.002.

107. Zhang $H$, Sun L, Wang Z, Deng M, Nie H, Zhang G, et al. Ncarbamylglutamate and L-arginine improved maternal and placental development in underfed ewes. Reproduction. 2016;151(6):623-35. https:// doi.org/10.1530/REP-16-0067.

108. Zeng X, Huang Z, Mao X, Wang J, Wu G, Qiao S. N-carbamylglutamate enhances pregnancy outcome in rats through activation of the PI3K/PKB/ mTOR signaling pathway. PLoS One. 2012;7(7):e41192. https://doi.org/10.13 71/journal.pone.0041192.

109. Guo P, Jiang ZY, Gao KG, Wang L, Yang XF, Hu YJ, et al. Low-level arginine supplementation $(0.1 \%)$ of wheat-based diets in pregnancy increases the total and live-born litter sizes in gilts. Anim Prod Sci. 2017;57(6):1091-6. https://doi.org/10.1071/an15156.

110. Li X, Bazer FW, Johnson GA, Burghardt RC, Frank JW, Dai Z, et al. Dietary supplementation with L-arginine between days 14 and 25 of gestation enhances embryonic development and survival in gilts. Amino Acids. 2014; 46(2):375-84. https://doi.org/10.1007/s00726-013-1626-6.

111. Berard J, Bee G. Effects of dietary l-arginine supplementation to gilts during early gestation on foetal survival, growth and myofiber formation. Animal. 2010:4(10):1680-7. https://doi.org/10.1017/S1751731110000881.
112. Luise D, Bertocchi M, Bosi P, Correa F, Spinelli E, Trevisi P. Contribution of Larginine supplementation during gestation on sow productive performance and on sow microbial faecal profile. Ital J Anim Sci. 2020;19(1):330-40. https://doi.org/10.1080/1828051x.2020.1743210.

113. Gao K, Jiang Z, Lin Y, Zheng C, Zhou G, Chen F, et al. Dietary L-arginine supplementation enhances placental growth and reproductive performance in sows. Amino Acids. 2012;42(6):2207-14. https://doi.org/10.1007/s00726011-0960-9.

114. Che L, Yang $P$, Fang $Z$, Lin $Y$, Wu D. Effects of dietary arginine supplementation on reproductive performance and immunity of sows. Czech J Anim Sci. 2013:58(4):167-75. https://doi.org/10.17221/6711-Cjas.

115. Hong J, Fang LH, Jeong JH, Kim YY. Effects of L-arginine supplementation during late gestation on reproductive performance, piglet uniformity, blood profiles, and milk composition in high prolific sows. Animals (Basel). 2020; 10(8):1313. https://doi.org/10.3390/ani10081313.

116. Nuntapaitoon M, Muns R, Theil PK, Tummaruk P. L-arginine supplementation in sow diet during late gestation decrease stillborn piglet, increase piglet birth weight and increase immunoglobulin G concentration in colostrum. Theriogenology. 2018;121:27-34. https://doi.org/10.1016/j. theriogenology.2018.08.012.

\section{Ready to submit your research? Choose BMC and benefit from:}

- fast, convenient online submission

- thorough peer review by experienced researchers in your field

- rapid publication on acceptance

- support for research data, including large and complex data types

- gold Open Access which fosters wider collaboration and increased citations

- maximum visibility for your research: over $100 \mathrm{M}$ website views per year

At BMC, research is always in progress.

Learn more biomedcentral.com/submissions 